\title{
Editorial
}

\section{INTRODUCTION TO VOLUME 7(2)}

It is our great pleasure to bring you Volume 7(2) of the Cambridge International Law Journal (CILJ). As is customary for the Journal, this issue is a special one dedicated to a selection of the finest papers presented at the 2018 Cambridge International Law Conference. We will leave it to the conference convenors to guide you through the conference papers and to acknowledge those who contributed to the event's success.

We would first like to introduce the two articles which were not presented at the Conference but which are of such a high quality that we could not pass up on publishing them. The two papers share a common doctrinal methodology in analysing the jurisprudence of the European Court of Human Rights (ECtHR) to say something novel about the law. Focusing on disability rights, Andrea Broderick examines the ECtHR's development of the social dimension of certain civil-political rights by analysing the impact of the United Nations Convention on the Rights of Persons with Disabilities (CRPD) on the court's interpretation of disability rights under the European Convention on Human Rights. Broderick argues that the court's current approach to disability rights is too fragmented and could be moulded into a more principled approach, guided by the CRPD. In the next article, Agustín Ruiz Robledo considers the jurisprudence of this court in another area, that of elections. Robledo analyses the ECtHR's jurisprudence on the right to free elections contained in Article 3 of Protocol No 1 in order to show how it had single-handedly transformed an obligation on State parties to hold free elections into an individual right to free elections. Robledo then spells out the precise content and limits of this right as has been pronounced variously in ECtHR case law. This issue closes with a review by Eirini Kikarea of Reconceptualizing International Investment Law from the Global South edited by Fabio Morosini and Michelle Ratton Sanchez Badin. Kikarea finds much of use in this edited collection for both practitioners and scholars interested in seeing and reforming the investment law regime from a non-Western perspective.

Finally, as we come to the end of our term as joint Editors-in-Chief, we would like to thank the following people: our Honorary Editor-in-Chief, Professor Eyal Benvenisti; our Advisors; members of our Academic Review Board for their rigorous reviews; Treasurer, Ivan Lee; Managing Editors, Orfeas Chasapis-Tassinis, Trina Malone, Luíza Leão Soares Pereira, Maayan Menashe and Kim Willey; our conference convenors for 2018, Kaara Martinez and Patrick Perillo; and our editorial and blog teams. We send special thanks to the team at Edward Elgar Publishing, including Ben Booth, Katie Smith, Marina Bowgen and Nick Wilson, who patiently and professionally guided us through both issues from beginning to end. We are confident that the Journal and our collaboration with Edward Elgar will continue to flourish in the capable hands of our successors, Eirini Kikarea and Maayan Menashe. We wish them every success for Volume 8. 


\section{INTRODUCTION TO THE CONFERENCE}

On 3-4 April 2018, the Journal convened its 7th annual Conference under the theme of 'Non-State Actors and International Law'. We debated for some time whether such a vast and seemingly well-worn topic in the field would be right for this year's conference. On the one hand, it would allow a broad cross-section of presenters and papers; yet, on the other, we wanted to be sure the Conference would offer incisive and innovative perspectives and contributions to international legal debate. The Call for Papers thus asked for scholarly research focusing on more traditional conceptualisations of non-state actors in international law, such as armed groups and transnational corporations, as well as research exploring intersections with new technologies, development and society.

The Call for Papers attracted over 300 abstract submissions, indicating that the issue of non-state actors and international law remains highly current, and that there are indeed fresh and evolving manifestations of this long-standing debate in the field. Reviewing this volume of abstracts was an overwhelming task, not least because the submissions were highly varied in exploring the Conference theme in nuanced and unexpected ways, offering theoretical perspectives as well as practical case studies and empirical research. We were extremely grateful for this positive response, and remain extremely proud of the programme we were able to compile as a result. Over the two days, we hosted 54 presenters across 13 panels ranging from international courts, non-state armed groups, conflict and human rights, to corporate accountability, business and international economic law, to discussions on social media, cities, and the air, space and sea. The diversity of the Conference was reflected also in our presenters and participants who represented not just the UK and Europe, but also North and South America, Australia, China, New Zealand, Nigeria, Pakistan and South Africa among other countries and regions, and representing academia, non-profit organisations and the private sector.

The Conference issue of the Journal provides an intellectual snapshot of those two days. It offers five articles from the 54 presentations. The articles featured here carefully bring into focus some of the less traditional notions of non-state actors in international law which have grown in prominence, influence, and, consequently, importance through the years, and the authors offer judicious analyses of important contemporary issues.

Specifically, Tania Penovic and Ronli Sifris consider the role of international civil society in the context of women's reproductive rights. They focus on Australia's experience with targeted anti-abortion protests, and interrogate the effectiveness of legislation that has been put in place to curtail this practice. Using qualitative empirical research methods, they analyse the practices of these protest groups and the legislative responses through the 'feminisation dimension' of international law espoused by Professor Andrew Clapham.

In their respective articles, Róisín A Costello and Tsvetelina van Benthem offer interjections into one of the more recent and controversial areas of public debate around nonstate actors and international law: that of technological advancements and digital platforms. Costello evaluates the role of digital platform providers in preserving content, particularly that which has been removed as inappropriate or extremist, and responsibilities with respect to the sharing of such content to assist in the prosecution of international criminal offences at a future time. Costello specifically examines the role of the International Criminal Court in the context of social media and open source evidence. Van Benthem looks at the issue of new technologies as it relates to terrorism and observes that the use of algorithmic systems in screening terrorist content uploaded on digital platforms lacks the 'contextualised and nuanced decision-making' necessary for removing 
content online. Van Benthem proffers the view that this amounts to a state-induced content regulation, granting online intermediaries with a quasi-judicial function that may conflict with the right to freedom of expression, and proposes potential solutions to prevent such violation.

Finally, the issue includes two pieces reflecting on financial and economic actors in specific international legal contexts. Eva Kassoti's contribution provides an international law analysis of economic activities by businesses in occupied territories. She asserts that soft-law instruments such as the UN Guiding Principles on Business and Human Rights have been successful in discouraging businesses from certain economic activities in occupied territories despite the absence of any international legal instrument creating such an obligation, and expects hard law to eventually follow. Johanna Lorenzo posits that international financial institutions (IFIs) are important participants in international law-making, especially in sustainable development, providing avenues that enable other non-state actors to participate in law-making processes on an international level. She emphasises the 'safeguard systems' of IFIs and suggests that strengthening the independent accountability mechanism of these systems, which interprets the IFI's environmental and social policies, may prevent a race to the bottom in sustainability standards. The issue thus represents the strong and thoughtful range of discourse that marked the Journal's 7th annual Conference.

In closing, we note that we were extremely fortunate to have had a tremendous amount of support in bringing the Conference to fruition and we would like to offer our warmest thanks to all those involved. In particular, we are extremely grateful to the Conference Team - specifically, Rebecca Freund, Nell Hall, Natascha Kersting, Eirini Kikarea, Liang Li, Darren Peterson and Emma Rengers - who were patient, pleasant and enthusiastic throughout the six months of preparation. We are also very grateful to the Editors-in-Chief of the Journal, Richard Clements and Ya Lan Chang, for entrusting us with the Conference and for their complete support; as well as to the Journal Treasurer, Ivan Lee, with whom we worked very closely, and whose patience and efficiency ensured that registration and related matters went as smoothly as possible.

We are particularly appreciative of the academic support and guidance we received from Professor Eyal Benvenisti as well as the sponsorship of the Lauterpacht Centre for International Law. We are also delighted to have had Edward Elgar and Hart Publishing as publication partners at the Conference, and we are indebted to the Cambridge Law Faculty for providing the venue and other logistical support for the Conference and to the School of the Humanities and Social Sciences of the University of Cambridge for their generous funding award.

Our sincere gratitude is also extended to the Conference keynote speakers, Olivier De Schutter and Jorge E Viñuales, for their robust and engaging remarks, and for challenging us to rethink our ideas around and strategies concerning non-state actors. We are equally grateful to Michael Waibel, Rumiana Yotova and Kirsty Hughes for their respective special participation at the Conference. We would like to offer a huge thanks to our panel chairs who helped to foster penetrating and insightful thematic discussions and who stepped forward enthusiastically in support of the Conference, a student-led international law initiative at Cambridge, amid a challenging period for higher education in the United Kingdom.

Finally, our thanks go to the presenters and participants who brought the Conference to life. For us as Convenors, planning the Conference was an incredibly rewarding personal and professional endeavour which has deeply enhanced our total academic experience. We are thankful to have been able to call upon the 2017 conference convenors for 
198 Cambridge International Law Journal, Vol. 7 No. 2

assistance throughout, and eagerly look forward to the 2019 Conference which we are confident will once again attract high quality scholarship and rich debate. We hope that you will join us in Cambridge then, and that you will find the pages ahead in this issue a fruitful reminder of our collective efforts.

Kaara Martinez and Patrick Simon Perillo Conference Convenors 